\title{
A study of the evaluation of Perceived Stress, Depression and Anxiety amongst Covid-19 patients in a tertiary care hospital
}

\author{
Nimesh C. Parikh ${ }^{1}$, Anisha Balchandani ${ }^{2}$, Khevna Andharia ${ }^{3}$, Jyot Patel ${ }^{4}$, Daideepya Leuva ${ }^{5}$ \\ ${ }^{1}$ Professor and Head of The Department, Department of Psychiatry, NHLMMC, SVP Hospital, \\ Ahmedabad. \\ ${ }^{2} 3^{\text {rd }}$ Year Resident Doctor, Department of Psychiatry, NHLMMC, SVP Hospital, Ahmedabad. \\ ${ }^{3}$ 2nd Year Medical Student, NHLMMC, SVP Hospital, Ahmedabad. \\ ${ }^{4} 1$ st Year Medical Student, MK Shah Hospital, Ahmedabad. \\ ${ }^{5} 1$ st Year Medical Student, BJ Medical College, Ahmedabad. \\ Corresponding author: Anisha Balchandani \\ Email - anisha.666@gmail.com
}

\begin{abstract}
Background: COVID-19 is a significant health crisis affecting the world and at its heart are the HCWs treating the patients. However, only a few studies in India have addressed the potential effect on the mental health of HCWs. Thus, we decided to find the prevalence of Perceived Stress, Depression, and Anxiety of the Paramedical (PHCW) and Medical (MHCW) Healthcare Workers doing Covid Duty and correlate it with the duty related parameters.

Methodology: In a Tertiary Care Covid Hospital, we conducted a cross-sectional study of 203 HCWs (PHCWs \& MHCWs) assessed socio-demographic \& duty-related variables, stress by PSS, Depression by PHQ-9, and Anxiety by HAM-A after obtaining informed consent.

Results: Amongst the $203 \mathrm{HCWs}, 75.3 \%$ have significant perceived stress. $34 \%$ have mild to severe depression which is 3-4 times more than the general population. 7.88\% of HCWs have anxiety. PHCWs have significantly more anxiety $(11.88 \%)$ as compared to MHCWs $(3.92 \%)$ doing COVID duty. In duty related parameters, PHCWs working $>=6$ weeks have high stress $(45.54 \%)$ and depression $(24.75 \%)$ as compared to MHCWs. Despite doing duty in a stable ward, PHCWs have significantly high stress $(39.60 \%)$ and depression (19.8\%) as compared to MHCWs. MHCWs have significantly high Stress $(48.03 \%)$ and depression (16.67\%) while doing duty in both (ICU and ward) as compared to PHCWs.

Conclusion: Both PHCWs and MHCWs have a high prevalence of perceived stress and depression, with a significant difference due to duty-related Parameters - long duration and place of duty.
\end{abstract}

Key words: Healthcare Workers, Perceived Stress, Anxiety, Depression

(Paper received $-29^{\text {th }}$ August 2021, Peer review completed $-9^{\text {th }}$ September 2021)

(Accepted $-10^{\text {th }}$ October 2021, Published $-5^{\text {th }}$ January 2022)

\section{INTRODUCTION}

COVID-19 crisis has affected the entire world since it was declared a pandemic by WHO [1]. The people working tirelessly to bring the medical crisis under control since the onset of the epidemic are the healthcare workers. Apart from the physical exertion of wearing PPE and long working hours, they also have to face variable duty schedules, make ethically difficult decisions and fear contracting and spreading the infection [2]. Also, as per the study by Mohinder and others [3] worries of family members back home, risk of infection of friends and relatives, Hospital isolation, and hostility from society tests the resilience of HCWs. According to previous studies, during the outbreaks of Severe Acute Respiratory Syndrome (SARS) and the Middle East Respiratory Syndrome (MERS), frontline medical staff had reported high levels of stress that resulted in posttraumatic stress disorder (PTSD) [4]. 
According to a recent study in Wuhan [5], that assessed mental Health outcomes in HCWs in 20 hospitals, $50.4 \%$ reported depression and $44.6 \%$ reported anxiety. Also in India, a study [6] reported high-level Perceived stress in 3.7\% of Health Care Professionals working during the COVID 19 outbreak in April. Since HCWs are especially vulnerable to mental health problems, including anxiety and depression under high levels of stress [7], we felt that their mental angst needs to be put into surveillance and interventions for controlling it need to be taken. Thus, we chose Medical (MHCWs) and Paramedical Healthcare Workers (PHCWS) as our study population and aimed to assess and compare perceived stress amongst them, to assess and compare depression amongst them, to assess and compare the level of anxiety between them, to assess the impact of socio-demographic variables on perceived stress, depression, and anxiety and to assess the impact of duty-related parameters on perceived stress, depression, and anxiety amongst medical and paramedical health care workers.

\section{METHODOLOGY}

\section{Study design and Participants}

A cross-sectional study was carried out in a tertiary care hospital functioning as a COVID care center after approval from the Institutional Review Board during the month of June 2020. All consenting healthcare workers who had performed their duties for COVID-19 positive patients for at least 15 days were included. A total of 203 Paramedical and Medical Professionals were included. All Non-Consenting HCWs and those who had contracted or recovered from COVID infection were excluded.

\section{Measurements}

Both the groups, i.e. MHCWs and PHCWs were evaluated on the following parameters

1. Socio-demographic parameters like age, gender, marital status, education, religion, family type, and locality and clinical parameters like history of medical/psychiatric illness and addictions.

2. Duty Related parameters like number of days spent, days since the last COVID duty and its site.

There were 3 stress rating scales -

1. Perceived Stress Scale (PSS): This is a 10 item self-rated scale with Cronbach's alpha 0.78 [8]. It is a subjective scale with Scores 0-13 as low stress, 14-26 considered moderate stress $27-40$ considered high perceived stress.

2. Patient Health Questionnaire-9 (PHQ-9): This is a scale to predict the presence and severity of depression. It is a 9 item self-reported questionnaire with score $0-27$ and PHQ-9 score $\geq 10$ had a sensitivity of $88 \%$ and a specificity of $88 \%$ for major depression. PHQ-9 scores of $5,10,15$, and 20 represented mild, moderate, moderately severe, and severe depression, respectively [9].

3. Hamilton Anxiety Rating Scale (HAM-A): It is a 14 question objective scale for screening and assessing severity of anxiety with reliability as alpha $=0.77$ to 0.92 [10]. It is a 14-item questionnaire with 14-17 = Mild Anxiety 18-24 = Moderate Anxiety 25-30 = Severe Anxiety.

\section{STATISTICAL ANALYSIS}

Statistical analysis was done using IBM SPSS Statistics for Windows, version 20, Armouk, NY, USA [11]. Descriptive statistical analysis was used for Socio-demographic, Clinical, Duty related Parameters, PSS, PHQ-9 and HAM-A. Proportions were used for discrete variables. Suitable parametric/non-parametric tests were applied for finding significant statistical differences.

\section{RESULTS}

A total of 203 consenting participants -101 PHCWs and 102 MHCWs (all Resident Doctors) were included. 
Sociodemographic and Clinical Parameters

According to table 1 showing Socio-demographic and clinical parameters, Most of PHCWs were Male (54.45\%), $>27$ years old (50.49\%), married(54.45\%), Graduate(64.35\%), living in nuclear family $(73.26 \%)$ in Urban Area (61.38\%). MHCWs predominantly consisted of single(93.13\%), male (63.72\%), <27 years old $(90.19 \%)$, graduates $(100 \%)$, of a joint family $(63.73 \%)$ living in urban area $(96.07 \%)$, Majority participants refused for addiction $(97.02 \%$ PHCWs and $98.03 \% \mathrm{MCWs})$ had no History of psychiatric illness $(98.01 \%$ and 99.02\%) and no History of Medical illness (PHCWs 97.02 and MHCWs 94.11\%).

Table 1: Comparison of Sociodemographic and Clinical Parameters between Paramedical Health care workers and Medical Health care workers doing duty in COVID Positive Admitted Patients

\begin{tabular}{|l|l|l|l|}
\hline $\begin{array}{l}\text { Sociodemographic \& } \\
\text { Clinical Parameters }\end{array}$ & $\begin{array}{l}\text { Paramedical } \\
\text { Health care } \\
\text { workers (n=101) }\end{array}$ & $\begin{array}{l}\text { Medical Health } \\
\text { care workers } \\
\text { (n=102) }\end{array}$ \\
\hline \multirow{2}{*}{ Age (years) } & $<=27$ years & $50(49.50 \%)$ & $92(90.19 \%)$ \\
\cline { 2 - 4 } & $>27$ years & $51(50.49 \%)$ & $10(9.80 \%)$ \\
\hline \multirow{2}{*}{ Gender } & Male & $55(54.45 \%)$ & $65(63.72 \%)$ \\
\cline { 2 - 4 } & Female & $46(45.54 \%)$ & $37(36.27 \%)$ \\
\hline \multirow{2}{*}{ Education } & Single & $46(45.54 \%)$ & $95(93.13 \%)$ \\
\cline { 2 - 4 } & Married & $55(54.45 \%)$ & $7(6.86 \%)$ \\
\hline \multirow{2}{*}{ Locality } & Graduate & $65(64.35 \%)$ & $102(100 \%)$ \\
\cline { 2 - 4 } & Post Graduate & $36(35.64 \%)$ & 0 \\
\hline \multirow{2}{*}{ Family Type } & Urban & $62(61.38 \%)$ & $98(96.07 \%)$ \\
\cline { 2 - 4 } & Rural & $39(38.61 \%)$ & $4(3.92 \%)$ \\
\hline \multirow{2}{*}{ Addiction } & Nuclear & $74(73.26 \%)$ & $28(27.45 \%)$ \\
\cline { 2 - 4 } & Joint/Extended & $36(35.64 \%)$ & $65(63.73 \%)$ \\
\hline \multirow{2}{*}{ History of Psychiatric Illness and } & $\begin{array}{l}\text { Smoking/Other } \\
\text { Treatment Taken }\end{array}$ & $3(2.97 \%)$ & $2(1.96 \%)$ \\
\cline { 2 - 4 } & No & $98(97.02 \%)$ & $100(98.03 \%)$ \\
\hline History of Medical Illness & Yes & $2(0.02 \%)$ & $1(0.98 \%)$ \\
\hline & Yes & $99(98.01 \%)$ & $101(99.02 \%)$ \\
\hline & No & $3(2.97 \%)$ & $6(5.88 \%)$ \\
\hline
\end{tabular}

\section{Duty Related Parameters}

According to Table 2, showing Duty Related Parameters, 92.07\% PHCWs and 93.13\% MHCWs had performed Covid duty less than 7 days ago. 63.36\% PHCWs compared to 24.51\% MHCWs had spent more than 6 weeks doing Covid work with a significant difference of $<0.0001$. Also a similar result, (p Value $=$ $<0.00001$ ) was found with $57.54 \%$ MHCW working in both ICU and ward, while $51.48 \%$ PHCWs had worked in a stable ward.

Table 2: Comparison of Duty Related parameters between PHCWs and MHCWs Doing duty in COVID Positive Admitted patients

\begin{tabular}{|c|c|c|c|c|c|}
\hline $\begin{array}{l}\text { Duty Related } \\
\text { Parameters }\end{array}$ & & $\begin{array}{l}\text { Medical Health } \\
\text { Care Workers } \\
(\mathrm{n}=101)\end{array}$ & $\begin{array}{l}\text { Paramedical Health } \\
\text { Care Workers } \\
(\mathrm{n}=102)\end{array}$ & & Significance \\
\hline \multirow{2}{*}{$\begin{array}{l}\text { Last covid Duty } \\
\text { before }\end{array}$} & $<=7$ days & $93(92.07 \%)$ & $95(93.13 \%)$ & \multirow[t]{2}{*}{0.083} & \multirow{2}{*}{$\begin{array}{l}0.773247 \\
\text { Not Significant }\end{array}$} \\
\hline & $>7$ days & $8(7.92 \%)$ & $7(6.86 \%)$ & & \\
\hline \multirow{3}{*}{$\begin{array}{l}\text { No of days spent in } \\
\text { covid duty }\end{array}$} & $>=6$ weeks & $64(63.36 \%)$ & $25(24.51 \%)$ & \multirow[t]{3}{*}{32.5667} & \multirow{3}{*}{$\begin{array}{l}<0.00001 \\
\text { Significant* }\end{array}$} \\
\hline & 4-6 weeks & $23(22.77 \%)$ & $38(37.25 \%)$ & & \\
\hline & 2-4 weeks & $14(13.86 \%)$ & $39(38.24 \%)$ & & \\
\hline
\end{tabular}




\begin{tabular}{|l|l|l|l|l|l|}
\hline \multirow{3}{*}{ Duty in } & ICU & $27(26.73 \%)$ & $18(17.64 \%)$ & 28.1645 & $<0.00001$ \\
\cline { 2 - 4 } & Stable ward & $52(51.48 \%)$ & $25(24.50 \%)$ & & \multirow{2}{*}{ Significant* } \\
\cline { 2 - 4 } & Both & $22(21.78 \%)$ & $59(57.84 \%)$ & & \\
\hline
\end{tabular}

${ }^{*} \mathrm{p}$ value $<0.05$ is considered statistically significant.

Table 3: Prevalence and comparison of Perceived stress among PHCWs and MHCWs Doing duty in COVID Positive Admitted patients

\begin{tabular}{|c|c|c|c|c|}
\hline & $\begin{array}{l}\text { Paramedical } \\
\text { Health care } \\
\text { workers (n=101) }\end{array}$ & $\begin{array}{l}\text { Medical Health } \\
\text { care workers } \\
(\mathbf{n = 1 0 2})\end{array}$ & $\begin{array}{l}\text { Chi } \\
\text { Square }\end{array}$ & $\begin{array}{l}\text { P value and } \\
\text { significance }\end{array}$ \\
\hline $\begin{array}{c}\text { Low Perceived stress } \\
(\mathbf{0 - 1 3 )}\end{array}$ & $28(27.72 \%)$ & $22(21.56 \%)$ & 1.0354 & $\begin{array}{c}0.308903 \\
\text { Not Significant }\end{array}$ \\
\hline $\begin{array}{c}\text { Moderate- high } \\
\text { Perceived }\end{array}$ & $73(73.73 \%)$ & $80(78.43 \%)$ & \\
\hline
\end{tabular}

According to Table 3, After assessing Perceived stress in PHCWs and MHCWs, $73.73 \%$ PHCWS and $78.43 \%$ MHCWS had moderate - high levels of Perceived stress ( $p$ value 0.308903 , Not Significant)

Table 4. Prevalence and comparison of Depression (PHQ-9) among PHCWs and MHCWs Doing duty in COVID Positive Admitted patients

\begin{tabular}{|l|l|l|l|l|}
\hline & $\begin{array}{l}\text { Paramedical Health } \\
\text { care workers } \\
(\mathbf{n}=\mathbf{1 0 1})\end{array}$ & $\begin{array}{l}\text { Medical Health care } \\
\text { workers (n=102) }\end{array}$ & $\begin{array}{l}\text { Chi } \\
\text { Square test }\end{array}$ & $\begin{array}{l}\text { P value and } \\
\text { significance }\end{array}$ \\
\cline { 1 - 3 } $\begin{array}{l}\text { No- Minimal } \\
\text { Depression (0-4) }\end{array}$ & $62(62.39 \%)$ & $72(70.59 \%)$ & 1.9153 & 0.166375 \\
\cline { 1 - 3 } $\begin{array}{l}\text { Mild- severe } \\
\text { Depression (5-27) }\end{array}$ & $39(38.61 \%)$ & $30(29.41 \%)$ & Not Significant \\
\hline
\end{tabular}

According to table 4. Showing Prevalence of Depression, 34\% HCWs $38.61 \%$ PHCWs and $29.41 \%$ MHCWs were found to suffer from mild- severe Depression. This is 3-5 times more than the general population [12]

Table 5: Prevalence and comparison of Anxiety (HAM-A) among PHCWs and MHCWs Doing duty in COVID Positive Admitted patients

\begin{tabular}{|c|c|c|c|c|}
\hline & $\begin{array}{l}\text { Paramedical Health } \\
\text { care workers }(n=101)\end{array}$ & $\begin{array}{l}\text { Medical Health care } \\
\text { workers }(n=102)\end{array}$ & Chi Square & $\begin{array}{l}P \text { value and } \\
\text { significance }\end{array}$ \\
\hline No Anxiety (0-13) & $89(88.12 \%)$ & $98(96.08 \%)$ & \multirow[t]{2}{*}{4.4283} & \multirow{2}{*}{$\begin{array}{l}0.035347 \\
\text { Significant * }\end{array}$} \\
\hline Mild- Severe (>14) & $12(11.88 \%)$ & $4(3.92 \%)$ & & \\
\hline
\end{tabular}

According to table 5, Mild to Severe Anxiety was Prevalent among 7.88\% of HCWs. PHCWs have significantly ( $\mathrm{p}$ value $=0.035347$ ) more anxiety $(11.88 \%$ ) as compared to MHCWs $(3.92 \%$ ) doing Covid Duty. 
Table 6: Correlation of Moderate - high Perceived stress and Duty Related parameters amongst PHCWs and MHCWs Doing duty in CoVID + Admitted patients

\begin{tabular}{|c|c|c|c|c|}
\hline Variables & $\begin{array}{l}\text { Paramedical } \\
\text { Health care } \\
\text { workers }(n=101)\end{array}$ & $\begin{array}{l}\text { Medical Health } \\
\text { care workers } \\
(\mathrm{n}=102)\end{array}$ & $\begin{array}{l}\text { Chi } \\
\text { Square }\end{array}$ & $\begin{array}{l}P \text { value and } \\
\text { significance }\end{array}$ \\
\hline Last Covid Duty Before & $\begin{array}{l}\text { Moderate-high } \\
\text { Perceived Stress } \\
(14-40)\end{array}$ & $\begin{array}{l}\text { Moderate-high } \\
\text { Perceived Stress } \\
(14-40)\end{array}$ & \multirow[t]{3}{*}{1.20} & \multirow[t]{3}{*}{$\begin{array}{l}0.272391 \\
\text { Not } \\
\text { Significant }\end{array}$} \\
\hline$<=7$ days & $66(65.35 \%)$ & $76(74.51 \%)$ & & \\
\hline$>7$ days & $7(6.93 \%)$ & $4(3.92 \%)$ & & \\
\hline $\begin{array}{l}\text { Number of days spent in } \\
\text { covid duty } \\
>=6 \text { weeks }\end{array}$ & $46(45.54 \%)$ & $20(19.60 \%)$ & \multirow[t]{3}{*}{22.9009} & \multirow[t]{3}{*}{$\begin{array}{l}0.000011 \\
\text { Significant* }\end{array}$} \\
\hline 4-6 weeks & $17(16.83 \%)$ & $33(32.35 \%)$ & & \\
\hline $2-4$ weeks & $10(9.90 \%)$ & $27(26.47 \%)$ & & \\
\hline $\begin{array}{l}\text { Duty in } \\
\text { ICU }\end{array}$ & $17(16.83 \%)$ & $14(13.72 \%)$ & \multirow[t]{3}{*}{26.0592} & \multirow[t]{3}{*}{$\begin{array}{l}<0.0001 \\
\text { Significant* }\end{array}$} \\
\hline Stable ward & $40(39.60 \%)$ & $17(16.67 \%)$ & & \\
\hline Both & $16(15.84 \%)$ & $49(48.03 \%)$ & & \\
\hline
\end{tabular}

Table 7: Correlation of Presence of Mild- Severe Depression (PHQ-9) with the Duty Related Variables amongst PHCWs and MHCWs Doing duty in COVID positive admitted patients

\begin{tabular}{|c|c|c|c|c|}
\hline Variables & $\begin{array}{l}\text { Paramedical Health } \\
\text { care workers } \\
(\mathrm{n}=101)\end{array}$ & $\begin{array}{l}\text { Medical Health } \\
\text { care workers } \\
(\mathrm{n}=102)\end{array}$ & \multirow[t]{2}{*}{ Chi Square } & \multirow[t]{2}{*}{$\begin{array}{l}P \text { value and } \\
\text { significance }\end{array}$} \\
\hline Last Covid Duty Before & $\begin{array}{l}\text { Mild- Severe } \\
\text { Depression }(>4)\end{array}$ & $\begin{array}{l}\text { Mild- Severe } \\
\text { Depression }(>4)\end{array}$ & & \\
\hline$<=7$ days & $36(35.64 \%)$ & $27(26.47 \%)$ & \multirow[t]{2}{*}{0.1137} & \multirow{2}{*}{$\begin{array}{l}0.73593 \\
\text { Not Significant }\end{array}$} \\
\hline$>7$ days & $3(2.97 \%)$ & $3(2.94 \%)$ & & \\
\hline $\begin{array}{l}\text { Number of days spent } \\
\text { in covid duty } \\
>=6 \text { weeks }\end{array}$ & $25(24.75 \%)$ & $8(7.84 \%)$ & \multirow[t]{3}{*}{9.9756} & \multirow[t]{3}{*}{$\begin{array}{l}0.006821 \\
\text { Significant }\end{array}$} \\
\hline 4-6 weeks & $8(7.92 \%)$ & $10(9.80 \%)$ & & \\
\hline 2-4 weeks & $6(5.94 \%)$ & $12(11.76 \%)$ & & \\
\hline $\begin{array}{l}\text { Duty in } \\
\text { ICU }\end{array}$ & $9(8.91 \%)$ & $5(4.90 \%)$ & \multirow[t]{3}{*}{7.0465} & \multirow[t]{3}{*}{$\begin{array}{l}0.29503 \\
\text { Not Significant }\end{array}$} \\
\hline Stable ward & $20(19.80 \%)$ & $8(7.84 \%)$ & & \\
\hline Both & $10(9.90 \%)$ & $17(16.67 \%)$ & & \\
\hline
\end{tabular}

According to Table 6, Showing Correlation of High levels of Perceived stress, Mild- severe Depression, and Mild - severe Anxiety with duty related parameters, after completing $>=6$ weeks in Covid duty $45.54 \%$ PHCWs had moderate to high levels of perceived stress as compared to $19.60 \%$ of MHCWs with a significant difference of $\mathrm{P}$ value - 0.000011 . According to the place of duty, $48.03 \%$ MHCWs working both in ICU and ward had moderate to high Perceived stress which was significantly ( $\mathrm{P}$ value $<0.0001$ ) higher than PHCWs (15.84\%). 69.95\% of HCWs (65.35\% PHCWs and 74.51\%MHCWs ) who had completed their duties within the last 7 days or were still on duty suffered from moderate - high levels of perceived stress. According to table 7, 35.64\% PHCWs and $26.47 \% \mathrm{MHCWs}$ with depressive symptoms had been doing duty/had completed duty within the last 7 days. $24.75 \%$ of PHCWs who had done duty for more than equal 
to 6 weeks had depressive symptoms as compared to $7.84 \%$ MHCWs, P value- $0.006821 .16 .67 \%$ MHCWs with duty in both ICU and ward and 19.80\% PHCWs with stable ward duty had depression.

Table 8: Correlation of Mild Anxiety and Duty Related parameters amongst PHCWs and MHCWs Doing duty in COVID positive admitted patients

\begin{tabular}{|c|c|c|c|c|}
\hline Variables & $\begin{array}{l}\text { Paramedical } \\
\text { Healthcare } \\
\text { Workers }(\mathrm{N}=101)\end{array}$ & $\begin{array}{l}\text { Medical } \\
\text { Healthcare } \\
\text { Workers }(\mathrm{N}=102)\end{array}$ & \multirow[t]{2}{*}{$\begin{array}{l}\text { Chi } \\
\text { Square }\end{array}$} & \multirow[t]{2}{*}{$\begin{array}{l}\text { P value and } \\
\text { significance }\end{array}$} \\
\hline Last Covid Duty Before & $\begin{array}{l}\text { Moderate- high } \\
\text { Perceived stress } \\
(14-40)\end{array}$ & $\begin{array}{l}\text { Moderate- high } \\
\text { Perceived stress } \\
(14-40)\end{array}$ & & \\
\hline & $\begin{array}{l}\text { Mild - Severe } \\
\text { Anxiety }(>14)\end{array}$ & $\begin{array}{l}\text { Mild - Severe } \\
\text { Anxiety }(>14)\end{array}$ & \multirow{3}{*}{0.0187} & \multirow{3}{*}{$\begin{array}{l}0.891305 \\
\text { Not Significant }\end{array}$} \\
\hline$<=7$ days & $11(10.89 \%)$ & $4(3.92 \%)$ & & \\
\hline$>7$ days & $1(0.99 \%)$ & 0 & & \\
\hline $\begin{array}{l}\text { Number of days } \\
\text { spent in covid duty } \\
>=6 \text { weeks }\end{array}$ & $1(0.99 \%)$ & $1(0.98 \%)$ & \multirow{3}{*}{0.8} & \multirow{3}{*}{$\begin{array}{l}0.67032 \\
\text { Not Significant }\end{array}$} \\
\hline 4-6 weeks & $3(2.97 \%)$ & $1(0.98 \%)$ & & \\
\hline 2-4 weeks & $8(7.92 \%)$ & $2(1.96 \%)$ & & \\
\hline $\begin{array}{l}\text { Duty in } \\
\text { ICU }\end{array}$ & $4(3.96 \%)$ & $1(0.98 \%)$ & \multirow{3}{*}{0.1143} & \multirow{3}{*}{$\begin{array}{l}0.944459 \\
\text { Not Significant }\end{array}$} \\
\hline Stable ward & $5(4.95 \%)$ & $2(1.96 \%)$ & & \\
\hline Both & $3(2.97 \%)$ & $1(0.98 \%)$ & & \\
\hline
\end{tabular}

According to table 8 , In our study, out of $7.88 \%$ HCWs who had Anxiety either had COVID duty within the last 7 days $(7.38 \% \mathrm{HCWs})$, or were new to duty i.e had completed $2-4$ weeks $(4.93 \% \mathrm{HCWs})$, or had duty in stable ward $(3.45 \% \mathrm{HCWs})$.

\section{DISCUSSION}

To our knowledge, there are a few studies in India, assessing the levels of stress, anxiety and depression in frontline workers of COVID epidemic. For interview techniques, Wilson et al [6] used Google forms and Lai Et al [5] used verbal consents while we did in-person interviews after written consent which we believe helped us provide Support immediately. In our study we assessed $49.75 \%(\mathrm{n}=101)$ PHCWs (ie Nurses and Technicians) and $50.24 \%(\mathrm{n}=102)$ MHCWs (Residents doctors) which is almost equal, in order to remove any discrepancy in responses between the 2 groups and compare them.

In the present study, most of the HCWs were men $(59.11 \%)$, who had graduated $(82.27 \%)$. Which is in contrast with study by Lai et al [5] with majority participants of married (66.7\%) women (76.7\%) who were undergraduates (75.8\%). Also,92.97\% PHCWs and 93.13\% MHCWs had last Covid duty less than a week ago, $86.14 \%$ PHCWs and $61.76 \%$ MHCWs had duty schedules lasting for more than 4 weeks and $21.78 \%$ PHCWs and $57.84 \%$ had duty in both ICU and ward. To our knowledge, no other study in India sufficiently highlighted the importance of prolonged work related parameters.

Among Clinical Parameters, Moderate to high levels of stress was found in $75.37 \%$ of HCWs which was almost equal (78.9\%) to a study conducted by William et al [6] In India. Such significant levels of Perceived stress continuing in a population of HCWs who are constantly fighting against COVID can be detrimental for their health and their quality of life. [13] In our study no significant difference was found in perceived stress levels between nursing staff and Doctors (P value-0.308903) as both had moderate to high levels of 
stress $(73.73 \%$ PHCWs and $78.43 \%$ MHCWs). This could be because both were managing crises at the frontline with prolonged duty hours.

Depressive features were seen in $34.01 \%$ HCWs which is almost 3-5 times the prevalence of depression before Covid. [12] Depressive features (PHQ $>4$ ) was seen in $49.4 \%$ of patients in a study by Wilson et al.[6] The probable causes for this decrease in population with depression could be coping with the initial stress and resolution of the confinement after termination of lockdown.

In our study $7.88 \%$ HCWs (11.88 \% PHCWs and $3.92 \%$ MHCWs) had mild to severe anxiety with a significant difference of $\mathrm{p}$ value -0.035327 . Whereas, Zhu and others [14] from Wuhan, China, had reported that among 5,062 HCPs, the prevalence rates of anxiety were $24.1 \%$. This difference could be because of the resilience of HCWs in India and a Delay of 3 months between the 2 studies wherein HCWs might have developed various ways of coping with their anxiety.

PHCWs working $>=6$ weeks have high stress $(45.54 \%)$ and depression $(24.75 \%)$ as compared to MHCWs (19.60\% and $7.84 \%$ respectively) Despite doing duty in a stable ward, PHCWs have significantly high stress (39.60\%) and depression (19.80\%) as compared to MHCWs (16.67\% and $7.84 \%)$. MHCWs have significantly high Stress (48.03\%) and depression (16.67\%) while doing duty in both (ICU and ward) as compared to PHCWs ( $15.84 \%$ and $9.90 \%$ respectively). This significant difference could be because of lower salary and hectic duty schedules of nursing staff. Also, rigorous training of MHCWs helps them to cope better [15]. There is no significant difference in Anxiety between PHCWs and MHCWs.

\section{CONCLUSION}

Most of the HCWs were men, who had completed graduation and were living in nuclear families in Urban areas with no history of Medical / Psychiatric illness or addiction. Maximum of HCWs had duty within 7 days, had spent more than 6 weeks, and had duty in both ICU and ward at the time of participating in the study. Moderate to high levels of perceived stress was present in both PHCWs and MHCWs. The prevalence of depression in HCWs was 3-5 times the prevalence in non-COVID times in the general population. Anxiety was almost comparable to the general population. On correlating duty of PHCWs and MHCWs to perceived stress and depression, significant difference was found with longer duration and combined site of duty.

The present study is a Cross-sectional study, therefore overall Stress, anxiety and depression could not be evaluated with Limited participants and no follow up. The study was conducted in a single centre in Ahmedabad, limiting the generalization of our findings to more affected areas.

\section{REFERENCES}

1. https://www.who.int/emergencies/diseases/novel-coronavirus-2019/question-and-answers-hub/q-adetail/q-a-coronaviruse

2. Pappa S, Ntella V, Giannakas T, Giannakoulis VG, Papoutsi E, Katsaounou P. Prevalence of depression, anxiety, and insomnia among healthcare workers during the COVID-19 pandemic: A systematic review and meta-analysis. Brain Behav Immun 2020;88:901-7.

3. Mohindra R, Ravaki R, Suri V, Bhalla A, Singh SM. Issues relevant to mental health promotion in frontline health care providers managing quarantined/isolated COVID19 patients. Asian J Psychiatry 2020;51:102084.

4. Tam CW, Pang EP, Lam LC, Chiu HF. Severe acute respiratory syndrome (SARS) in Hong Kong in 2003: stress and psychological impact among frontline healthcare workers. Psychol Med 2004;34(7):1197-1204.

5. Lai J, Ma S, Wang Y, Cai Z, Hu J, Wei N, Wu J, Du H, Chen T, Li R, Tan H. Factors associated with mental health outcomes among health care workers exposed to coronavirus disease 2019. JAMA Netw Open 2020;3(3):e203976.

6. Wilson W, Raj JP, Rao S, Ghiya M, Nedungalaparambil NM, Mundra H, Mathew R. Prevalence and predictors of stress, anxiety, and depression among healthcare workers managing COVID-19 pandemic in India: a nationwide observational study. Indian J Psychol Med 2020;42(4):353-8.

7. Spoorthy MS, Pratapa SK, Mahant S. Mental health problems faced by healthcare workers due to the COVID19 pandemic-A review. Asian J Psychiatry 2020;51:102119.

8. Sun Y, Gao L, Kan Y, Shi BX. The Perceived Stress Scale-10 (PSS-10) is reliable and has construct validity in Chinese patients with systemic lupus erythematosus. Lupus 2019;28(2):149-55. 
9. Monahan PO, Shacham E, Reece M, Kroenke K, Ong'Or WO, Omollo O, Yebei VN, Ojwang C. Validity/reliability of PHQ-9 and PHQ-2 depression scales among adults living with HIV/AIDS in western Kenya. J Gen Intern Med 2009;24(2):189-97.

10. Maier W, Buller R, Philipp M, Heuser I. The Hamilton Anxiety Scale: reliability, validity and sensitivity to change in anxiety and depressive disorders. J Affect Disord 1988;14(1):61-8.

11. IBM Corp. Released 2011. IBM SPSS Statistics for Windows, Version 20.0. Armonk, NY: IBM Corp

12. Arvind BA, Gururaj G, Loganathan S, Amudhan S, Varghese M, Benegal V, Rao GN, Kokane AM, Chavan BS, Dalal PK, Ram D. Prevalence and socioeconomic impact of depressive disorders in India: multisite population-based cross-sectional study. BMJ Open 2019;9(6):e027250.

13. Marshall LL, Allison A, Nykamp D, Lanke S. Perceived stress and quality of life among doctor of pharmacy students. Am J Pharmaceut Educ 2008 Dec 15;72(6):137.

14. Zhu Z, Xu S, Wang H, Liu Z, Wu J, Li G, Miao J, Zhang C, Yang Y, Sun W, Zhu S. COVID-19 in Wuhan: Immediate Psychological Impact on 5062 Health Workers. MedRxiv 2020;Jan 1.

15. Zwack J, Schweitzer J. If every fifth physician is affected by burnout, what about the other four? Resilience strategies of experienced physicians. Acad Med 2013;88(3):382-9.

$* * * * * * * * * * * * * * * * * * * * * * * * * * * * * * * * * * * *$

Acknowledgements - Nil

Conflict of Interest $-\mathrm{Nil}$

Funding - Nil 